\title{
Applicability of the Spanish Version of the Supports Intensity Scale (SIS), in the Mexican Population with Severe Mental Illness
}

\author{
Maribel Cruz Ortiz ${ }^{1}$ \\ Cristina Jenaro Río \\ Ma. Del Carmen Pérez Rodríguez ${ }^{3}$ \\ Noelia Flores Robaina ${ }^{4}$
}

This study presents the results obtained from the evaluation, by specialist judges, of the Supports Intensity Scale (SIS), Spanish version, to determine its suitability for the Mexican population with severe mental illness (SMI). The instrument, originally designed for people with intellectual disabilities, is consistent with the multidimensional concept of quality of life and the social model of disability. The semantic equivalence of the items adjusted by specialist judges, the reliability of the subscales, using Cronbach's alpha, and the concurrent validity between the SIS and the Global Functioning Assessment (GAF) were analyzed. The mean similarity to the original was 9.91 from a total of $10(s d=0.14)$. The reliability coefficients were above 0.95 and the correlations between the SIS and the GAF were medium to high and significant. In conclusion, in the Mexican context, the SIS scale can be used to understand the needs and expectations of people with mental illness.

Descriptors: Disabled Persons; Needs Assessment; Mental Disorders.

\footnotetext{
${ }^{1}$ RN, Doctoral Student, Instituto Superior de Integración a la Comunidad, Universidad de Salamanca, Spain. E-mail: redazul@ hotmail.com.

2 Ph.D. in Psychology, Full Professor, Facultad de Psicología, Universidad de Salamanca, Spain. E-mail: crisje@usal.es.

${ }^{3}$ Ph.D. in Nursing, Professor, Facultad de Enfermería de San Luís Potosí, Universidad Autónoma de San Luís Potosí, México. E-mail: salina67@hotmail.com.

${ }^{4}$ Ph.D. in Psychology, Assistant Professor, Facultad de Psicología, Universidad de Salamanca, Spain. E-mail: nrobaina@usal.es.
}

Corresponding Author:

Ma. del Carmen Pérez Rodríguez

Universidad Autónoma de San Luis Potosí. Facultad de Enfermería.

Av. Niño Artillero No.130

Zona Universitaria

78400 San Luis Potosi, México

E-mail: salina67@hotmail.com 


\title{
Aplicabilidade da versão espanhola da escala de intensidade de apoio, na população mexicana com doença mental severa
}

Estão apresentados, aqui, os resultados obtidos da avaliação por juízes especialistas sobre a escala de intensidade de apoio (Scale Intensity Support-SIS), na versão espanhola, para determinar a sua aplicabilidade na população mexicana com doença mental severa (DMS). O instrumento, inicialmente concebido para pessoas com deficiência intelectual, é coerente com o conceito multidimensional de qualidade de vida e com o modelo social da deficiência. Foi analisada a equivalência semântica dos itens adotados, através dos juízes especialistas, a confiabilidade das subescalas, utilizando o alfa de Cronbach, e a validade concorrente entre as escalas SIS e a Global Assessment of Functioning (GAF). A média de semelhança com a original foi de 9,91 do máximo de $10(\mathrm{dp}=0,14)$. Os coeficientes de confiabilidade foram superiores a 0,95 e as correlações entre as escalas SIS e a GAF foram médias altas e significativas. Concluiu-se que, no contexto mexicano, a escala SIS pode ser utilizada para conhecer as necessidades e expectativas das pessoas com doença mental.

Descritores: Pessoas com Deficiência; Determinação de Necessidades de Cuidados de Saúde; Transtornos Mentais.

\section{Aplicabilidad de la escala de intensidad de apoyos (SIS), en población mexicana con enfermedad mental severa}

\begin{abstract}
Mostramos resultados obtenidos en la evaluación de jueces expertos en la Escala de Intensidad de Apoyos (SIS), versión española, para determinar su adecuación a la población mexicana con Enfermedad Mental Severa (EMS). El instrumento, originalmente diseñado para personas con discapacidad intelectual, es congruente con el concepto multidimensional de calidad de vida y el modelo social de discapacidad. Se analizó la equivalencia semántica de los ítems adaptados a través de jueces expertos, la fiabilidad de las subescalas mediante el coeficiente Alfa de Cronbach y la validez concurrente entre la SIS y la GAF. El promedio de semejanza con el original fue 9,91 sobre $10(D E=0,14)$. Los coeficientes de fiabilidad fueron superiores a 0,95 y las correlaciones entre la SIS y la GAF fueron entre medias y altas y significativas. Los resultados confirman que la escala SIS, con mínimas adecuaciones de forma, puede usarse para conocer las necesidades y expectativas en personas con enfermedad mental en el contexto mexicano.
\end{abstract}

Descriptores: Personas con Discapacidad; Evaluación de Necesidades; Trastornos Mentales.

\section{Introduction}

In recent years, serious efforts have been made to redefine disability, from a model that emphasizes the needs and disabilities of people, predominantly based on a biomedical perspective, to a social model, considering that disability is largely a result of the interaction of the person in a context that fails to provide them with the necessary support.
Therefore, the inclusion of the concept of support under the multidimensional reference of disability, strengthened by the concept of intellectual impairment of the American Association of Intellectual and Development Disabilities ${ }^{(1-4)}$ (AAIDD), becomes an indispensable element to understand the specific needs of people with disabilities in distinct areas, 
grouped according to the dimensions of quality of life proposed $^{(3-4)}$, and assumed in this work to address the collective of people with mental illness that only recently are being comprehended under the reference of disability.

The most consistent instrument with this theoretical concept is the Supports Intensity Scale, originally designed for people with intellectual disability(5). The model of support, implicit in the scale, is based on an ecological approach to understanding behavior, and is oriented to evaluate the discrepancy between the capacity and skills of the person and the requirements and demands necessary to function in a practical environment. Thus, the support is seen as resources and strategies that promote development, education, interests and personal well-being to improve individual functioning(6).

Resuming the multidimensional model of support of the AAIDD, the process of evaluation, under the concept of quality of life, advocates the need to focus both on the limitations of the individual as well as their capabilities, throughout their life.

The current focus of support is directly related to the incorporation of the perspective of Person Centered Planning (PCP), of results credited to the person, of promotion of competence, capacity building and strengthening the control of their lives for people with intellectual disability, in order to encourage the self-determination of people to achieve community integration ${ }^{(6-7)}$.

Bringing these principles to the practice requires the use of instruments that permit specific data about the support needs of each person to be obtained. The development of the individualized plan of intervention should be a consensus between the team, the user and their family(8). This complex situation has led to trying different approaches with generic and specific instruments, trying to answer problems in discipline and methodology, often hampered by the lack of conceptual models that support the research. From this the relevance of the alignment of the concept of quality with the paradigm of the reported supports ${ }^{(9-10)}$

In the context of mental health, particularly in psychiatry, research has been conducted from the perspective of quality of life related to symptomatology, and to its control. Extensive reviews show that psychiatric symptoms, in particular, and psychopathology in general are important, albeit modest, contributors to the quality of life of people with schizophrenia, and that the influence exercised by them depends in part on the sample of study(11). The mentioned authors emphasize the need to examine other psychosocial influences.

Numerous studies have been conducted with narrower approaches, focusing on the concept of health related quality of life (HRQOL) ${ }^{(12-13)}$, using tools like the Drug Attitude Inventory(14), the Global Assessment of Relational Functioning Scale(15), the SF-36 Health Questionnaire(16), the Lancashire Quality of Life Profile ${ }^{(17)}$ and also large instruments created ad hoc ${ }^{(18)}$. Most of these studies present a practical and common problem, which is the difficulty to translate the evaluations into plans of care, and to obtain results of quality of life, from the identification of the support needs of a person, i.e. to lead from possible to beyond the immediate reality. This is especially complex in the population that was the object of the study, if one considers that, much more often than in other fields, the reliability of perception of those affected is questioned(19), opting, to collect information from relatives or key informants.

The choice of an evaluation instrument is a complex task. In this sense, here there is agreement with those who think that the tools applicable to the population with mental illness must meet the following prerequisites: 1) be appropriate for the population to be studied and the stage of disease, and have adequate psychometric properties; 2) reflect the multidimensionality of the construct of quality of life in mental illness (schizophrenia, etc.); 3) due to the HRQoL being a subjective phenomenon, always include the self-report of the patients; 4) adapt to the life of patients and to cognitive impairments; 5 ) be consistent with the theoretical framework used by the investigator and 6 ) be sufficiently sensitive to change(20).

Previous approaches provide data to indicate the Supports Intensity Scale $\operatorname{SIS}^{(5)}$ as one of the most congruent instruments, with an updated concept of disability and quality of life, providing objective elements regarding the intensity of support required to achieve personal goals, which gives it an advantage over others by allowing the planning of services.

\section{Objective}

The aim of this study was to evaluate the applicability of the Supports Intensity Scale (SIS) (Spanish version), in the Mexican population with severe mental illness (SMI). 


\section{Method}

Design: this is an analytical study carried out in three stages. In the first, semantic analysis and adequation was carried out with professional and non professional specialists. In the second, the results of the pilot test were analyzed, to evaluate the behavior of the items of the scale. In the third, the instrument was applied to a large sample to determine the reliability of the subscales and of the complete scale.

Participants: for the first phase of the study a group of 11 professionals was chosen, covering a variety of health fields and in this subgroup of professionals, $36.4 \%$ were nurses, $27.3 \%$ psychologists, $18.2 \%$ psychiatrists and $18.2 \%$ social workers. In this group, the mean amount of professional experience was 13.3 years ( $s d=6.3$ years), $54.4 \%$ were specialists, $18.2 \%$ had an MSc or were technicians, and $9.2 \%$ had a teaching degree.

In the 2nd stage, the second subgroup of participants was chosen, formed by two focus groups, each consisting of 10 relatives of people with severe mental illness. Eighty percent of participants were women and had attended monthly meetings in some of these groups for two to five years.

For the implementation of pilot test of the SIS scale, people were randomly chosen who had severe mental illness (as defined by the NIMH in $1987^{(21)}$, and that, in the ICD-10 classification ${ }^{(22)}$, includes the codes F20-F22, F24, F25, F28-F31, F32.3, F33.3). Additional criteria for the sample selection were: disease duration exceeding two years; moderate or severe dysfunction of overall functioning (measured by GAF - Global Assessment of Functioning $1987^{(23)}$ ), being attended by the outpatient service; aged from 18 to 65 years; reliant on clinical care, participate in the consultation at least twice in the year 2008 and that at the time of application of the test, being accompanied by a person responsible for their care (primary caregiver), regardless of whether that person was a relative or not. Exclusion criteria were: existence of a state of turmoil or crisis, and/or the person with mental illness, or primary caregivers, to reject participation in the study.

The participants in the pilot test were 10 people with mental illness, to whom the SIS adapted scale was applied. The mean age was 35 years $(s d=8.2)$,
$30 \%$ were female and $70 \%$ male, $30 \%$ were single, $60 \%$ married and $10 \%$ separated. Regarding the employment situation, $40 \%$ were inactive. In relation to education, $30 \%$ had complete or incomplete elementary education, $40 \%$ complete or incomplete high school education, $20 \%$ higher education and $10 \%$ had not studied. The mean GAF score was 59.8 $(s d=11.6)$. Regarding diagnosis, chronic paranoid schizophrenia predominated (80\%) and $10 \%$ had bipolar affective disorder or mental and behavioral disorder secondary to brain dysfunction. The mean time since the appearance of the first crisis of the disease of the participants was 14.6 years $(s d=10.5)$.

In the third phase, to apply the study to a larger sample, we selected people with mental illness using the same criteria as the pilot test. The sample of participants consisted of 85 people with chronic mental illness, with a mean age of 38.28 years $(s d=11.75)$, of which $45.8 \%$ were female and $54.2 \%$ male. Regarding marital status, $61.5 \%$ were unmarried, $21.9 \%$ were married or living with a partner, $16.7 \%$ were separated and $2.1 \%$ widowed. The mean score obtained in the GAF was 59.84 ( $s d=11.60)$. With respect to medical diagnoses, $73.3 \%$ were diagnosed with chronic paranoid schizophrenia, followed by $12.6 \%$ with a diagnosis of bipolar affective disorder, less than $5 \%$ had diagnoses of schizoid affective disorder, mental and behavioral disorder secondary to cerebral dysfunction or major depression. The mean time since the first disease crisis was 14.56 years ( $s d=10.46)$, the mean number of hospitalizations was 3.6 ( $\mathrm{sd}=2.19)$, with a mean of 4.49 years $(s d=1.76)$ since the last hospitalization.

Procedure: The study was conducted in the State of San Luis Potosi, Mexico, a region located $363 \mathrm{~km}$ northeast of Mexico City. It has a total population $2,410,414$ inhabitants, $63 \%$ in the urban area and $37 \%$ in the rural ${ }^{(24)}$.

The procedure had three phases. In the first, the SIS scale was provided to a group of specialists for them, in the first instance, to evaluate the possibilities of using this scale in the Mexican population with severe mental illnesses. Additionally, they were requested to carry out a review of the scale, identifying the items that they considered necessary to reformulate, in whole or any part thereof, for semantic or conceptual issues, so that the scale was comprehensible for caregivers, patients and professionals. 


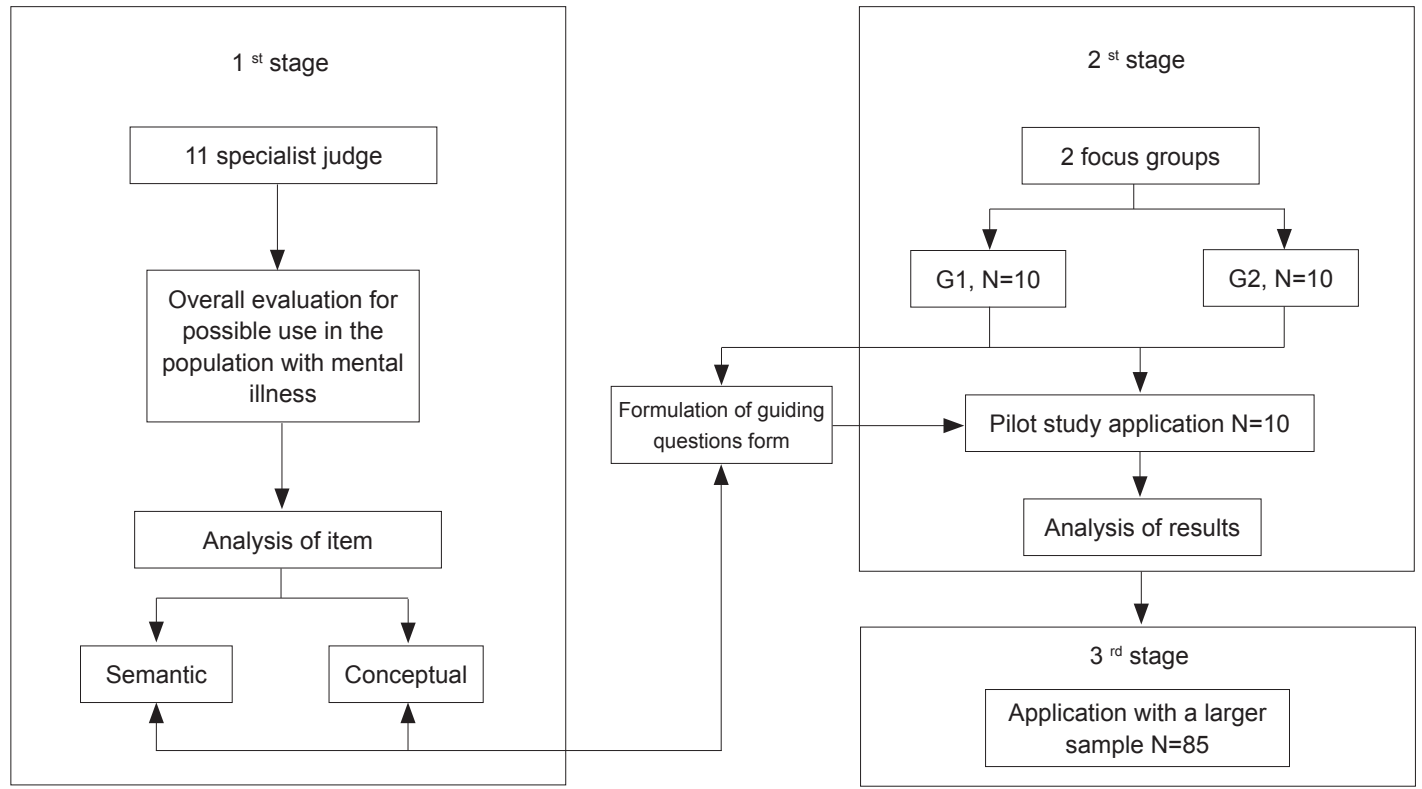

Figure 1 - Methodology for evaluating the applicability of the SIS scale in the Mexican population with DMS

The observations of the specialists were classified as to the utility of the scale, as to its application possibilities and as to the suggestions regarding necessary changes. At the same time, the group of families was called, and asked to read, together with the researcher, the items in each subscale. With both groups, two meetings of two hours duration each were carried out and, with prior consent, were audio-recorded and typed into digital format. The observations of the professional specialists and those of the family caregivers allowed the construction of a form containing guiding questions. This form was also given to the professionals to evaluate the consistency of the question with the item, using a scale of 1 to 10 . They were also asked to write down their suggestions or alternative questions to improve it. After this process, the specialists were asked to assess the similarity of the items adapted from the originals.

The scale was applied, then, as a pilot test, under the established inclusion criteria, to 10 people, using the adapted items and the guiding questions form. Sampling was carried out by accessing the medical records of the people treated in the State Health Services. The study was authorized in advance and was based on the General Health Law in relation to health research, in Title Five, Chapter One, Article 100, and $102^{(25)}$, as well as the principles of beneficence and non-maleficence. Informed consent was also requested from the participants.

The analysis of the pilot test was completed, without detecting difficulties in comprehension or application of the scale in the pilot test, neither on the part of the researcher nor the participants, proceeded to the application with the larger sample, to determine the reliability of the subscales and the total scale. Further analysis, omitted in this study, allows the support needs of this population to be characterized.

\section{Instruments}

In this study two instruments were used, the Supports Intensity Scale (SIS) ${ }^{(5)}$ and the Global Assessment of Functioning $(\mathrm{GAF})^{(23)}$. The SIS (Supports Intensity Scale adapted from the original Supports Intensity Scale, American Association on Intellectual and Developmental Disabilities ${ }^{(26)}$ ) is an instrument that provides information useful in identifying profiles and intensity of support needs. This measurement may serveto structure personalized plans for those with intellectual impairment and may represent policy to evaluate plans and programs structured with the information derived from its application. The instrument consists of three sections (scale of support needs, supplementary scale of protection and defense, and scale of exceptional needs of medical support and procedure), and also collects previously, the socio-demographic data of the person with intellectual impairment, the service provider and the informants who are providing the information. To measure the intensity of support, in the first two sections, with regard to parameters that evaluate three dimensions, namely: frequency, duration and type of support required by the person, with a scale of 0 to 4 . With the total scores, it is possible to obtain a profile of support needs and/or classify the intensity of support required. 
The scales of evaluation are provided by the manual of the Spanish version.

The Global Assessment of Functioning (GAF)(23) scale was applied in a manner complementary to the SIS, considering that its score is one of the criteria used to classify people with mental illness, within the group of people with severe mental illness. The GAF is the fifth axis in the DSM system. The purpose of the scale is to measure globally the severity of psychiatric illness, focusing on social, psychological and occupational functioning of the patient, using a cutoff score corresponding to the mild state (less than 70) in the less restrictive cases, or moderate (below 50) which indicates severity of symptoms, with severe effect on functioning and social competence.

\section{Results}

The data from the first phase of the study indicated that 18 items (36.7\%) were modified in their redaction. The mean of similarity to the original was 9.91 , with a maximum of $10(\mathrm{sd}=0.14)$. The mean score of similarity obtained for each scale, was in all cases greater than 9.5. The analysis of the consistency of the items from the SIS with the form of guiding questions, generated by relatives, indicated consistency mean of 9.8 in a maximum of $10(s d=0.4)$. The subscale $C$ (lifelong learning activities) obtained a lower mean score, with a mean of 9.6. The results also indicated the usefulness, when initiating the application of the scale, of defining the time period to which it relates, specifying the need to evaluate the person in chronic and not acute phases, because the periodic nature of mental illness can lead to overestimating the support needs during periods of crisis.

The analysis of the opinions of the relatives was similar to that of the experts as to how the SIS can help, among other things, to introduce the concept of disability within a social model into the field of mental illness. Table 1 shows the global results.

Table 1 - Descriptive Statistics (SIS) of the pilot sample application

\begin{tabular}{lcccc}
\hline & M [interval] & sd & Standard score & Percentile \\
\hline Home living activities & $17.80[8-27]$ & 6.56 & 8 & 25 \\
Community living activities & $17.70[4-38]$ & 12.71 & 8 & 25 \\
Lifelong learning activities & $38.00[3-69]$ & 19.98 & 8 & 25 \\
Employment activities & $31.50[3-61]$ & 19.16 & 9 & 37 \\
Health and safety activities & $17.20[7-34]$ & 8.93 & 7 & 16 \\
Social activities & $26.50[7-25]$ & 16.16 & 9 & 37 \\
Total & $148.70[61-275]$ & 76.08 & 49 & 27 \\
\hline
\end{tabular}

Finally, regarding the application of the scale to a large sample in order to determine the reliability of the subscales, the procedure followed by the authors of the adaptation of the scale(5) was replicated. First, a determination was carried out for the degree of relatedness of each subscale score with the age and gender of the individuals evaluated. In all cases, except in the correlation between the home life support needs and gender, the correlations were lower than 0.20, indicating negligible association between these variables. Consequently, neither age nor gender were considered relevant in the subsequent analysis of internal consistency. Table 2 shows the results derived from the calculation of internal consistency for each scale (Cronbach's alpha), and correlations between the variables indicated. We address also the correlations between the subscales and total of the SIS and the scores on the GAF, for concomitant validation, which are also shown.
Table 2 - Reliability coefficients (internal consistency) and correlations between the variables, gender and age

\begin{tabular}{lcccc}
\hline \multicolumn{1}{c}{ Subscales } & Alfa & $\mathbf{R}_{\mathrm{xy}}$ Age & $\mathbf{R}_{\mathrm{xy}}$ Gender & $\mathbf{R}_{\mathrm{xy}}$ GAF \\
\hline Home living activities & 0.95 & 0.034 & $0.242^{*}$ & $-.572^{* *}$ \\
Community living activities & 0.97 & -0.032 & 0.100 & $-.574^{* *}$ \\
Lifelong learning activities & 0.97 & 0.179 & 0.117 & $-.585^{* *}$ \\
Employment activities & 0.99 & 0.142 & 0.043 & $-.624^{* *}$ \\
Health and safety activities & 0.95 & 0.008 & 0.088 & $-.668^{* *}$ \\
Social activities & 0.96 & -0.004 & 0.184 & $-.590^{* *}$ \\
Total & 0.99 & 0.070 & 0.136 & $-.656^{* *}$ \\
\hline
\end{tabular}

*significance with $\mathrm{p}<0.05$; **significance with $\mathrm{p}<0.01$.

\section{Discussion}

The results of this study evaluate the usefulness of the SIS to determine the support needs of people with severe mental illness, for further implementation of interventions that provide answers to such needs. Put differently, the SIS is an instrument that, with minimal 
adjustments in form, can be used to understand the needs and expectations of people with mental illness. The evaluation of aspects related to the life in general of the person, within their context, not only in relation to their disease and disease symptoms, promotes integration and presents an evident need for more equitable access to basic forgotten opportunities, such as education, leisure, employment, justice etc.

The inclusion of items that relate not only to the current situation of the person, but also to hypothetical situations in possible contexts, and dimensions established for their measurement (frequency, duration and type) can provide concrete data useful for planning and designing services in the health context, and encourage caregivers and patients themselves to reflect on alternative care needs in areas that otherwise might not even be considered.

The self-application of the SIS scale in the state of San Luis Potosi, Mexico, is hardly feasible due to the lack of social integration of people with severe mental illness, which prevents the attainment of basic services, causing them emotional cognitive deterioration and reinforcing their social exclusion. The results obtained in the pilot group show, with the necessary precautions due to the small sample, that even within the group of people with chronic mental illness and severe symptoms it is possible to identify capabilities and limitations. Specifically, this group was located, globally, in the $27^{\text {th }}$ percentile of the scale, with homogeneous behavior. In the six subscales evaluated, the greatest needs for support were identified in the areas of employment and social activities $\left(37^{\text {th }}\right.$ percentile for both), and the one that registered less need for support was the subscale which referred to health and safety (16 $6^{\text {th }}$ percentile), with the analysis of the larger sample these results can be generalized and contextualized, in all cases, however, they clearly indicate two areas that are commonly perceived outside of the possibilities and requirements of this collective.

Finally, the scale applied to a larger group of people with mental illness presented adequate psychometric properties of reliability, comparable to those obtained by the authors of the Spanish adaptation. These results are, furthermore, independent of the age and gender of the individuals. Also, the correlations of medium to high intensity between the scores of the SIS and of the GAF offer support for the concurrent validity of the measure.

Although it is true that over the past five years, several papers have been published in the context of Nursing, addressing the theme of mental illness, these are predominantly directed towards the analysis of health services and models ${ }^{(27-29)}$ or toward the concept of mental illness ${ }^{(30-31)}$, centered on service quality ${ }^{(32-33)}$. They also lack instruments that tune the constructs of quality of life, disability and support systems, and which, in turn, provide tools which permit care planning and make the achievement of personal results possible. Accordingly, the instrument presented here, to be used in a population with mental illness can enable nurses to obtain solid data to plan care in an integral way.

\section{Conclusions}

Although there are limitations in this study, derived from its character as a pilot study, the data support the conceptual and empirical utility of the SIS scale for people with chronic mental illness. Subsequent work will compare the results obtained here.

\section{References}

1. Schalock R. Quality of life. Conceptualization and measurement. Whasington,D.C.; 1996.

2. AAMR. Mental Retardation. Definition, classification and systems of support. 10th ed. Whasington, D.C.: American Association on Mental Retardation; 1992.

3. Schalock R, Luckasson R, Shogren K. El nuevo concepto de retraso mental: comprendiendo el cambio al término discapacidad intelectual. Siglo Cero: Rev Española sob Discapacidad Intelectual. 2007; 38(224):5-20.

4. AAIDD. Intellectual disability: Definition, Classification, and Systems of Supports. 11th ed. Washington, DC: American Association on Intelectual and Developmental Disabilities; 2010.

5. Verdugo M, AriasB, Ibañez A. Escala de Intensidad de Apoyos. Manual (adaptación española del original: Supports Intensity Scale). Salamanca: INIC; 2007.
6. Verdugo M. Análisis de la definición de discapacidad intelectual de la asociación americana sobre retraso mental de 2002. Siglo Cero: Rev Española sob Discapacidad Intelectual. 2003; 34(205):5-19.

7. López M, Marín A, y de la parte J. La planificación centrada en la persona, una metodología coherente con el respeto al derecho de autodeterminación. Siglo Cero: Rev Española sob Discapacidad Intelectual. 2004; 35(210):45-55.

8. Laviana-Cuetos M. La atención a las personas con esquizofrenia y otros trastornos mentales graves desde los servicios públicos: una atención integral e integrada en un modelo comunitario. Apuntes Psicol 2006;24(1-3):345-73.

9. Schalock R. La nueva definición de discapacidad intelectual, los apoyos individuales y los resultados personales. Mejorando resultados personales para una calidad de vida. Salamanca: Amarú; 2009. 
10. Schalock R, Verdugo M, Bonham G, Fantova F, Van-Loon

J. Enhancing Personal Outcomes: Organizational Strategies, Guidelines, and Examples. J Policy Practice Intellectual Disabil. 2008; 5(1):18-28.

11. Eack S, Newhill C. Psychiatric Symptoms and Quality of Life in Schizophrenia: A Meta-Analysis. Schizophrenia Bull. 2007; 33(5):1225-37.

12. Eack S, Newhill C, Anderson C, Rotondi A. Quality of life for persons living with schizophrenia: more than just symptoms Psychiatr Rehabil J. 2007; 30(3):219-22.

13. Núñez D, Acuña F, Rojas G, Vogeln E. Construcción y validación inicial de un cuestionario para medir calidad de vida en pacientes esquizofrénicos. Rev Chilena Neuro-psiquiatría. 2007; 45(2):148-60.

14. Hamann J, Cohen R, Leucht S, Busch R, Kissling W. Do Patients With Schizophrenia Wish to Be Involved in Decisions About Their Medical Treatment? Am J Psychiatry 2005; 162:2382-4.

15. Hay P, Katsikitis M, Begg J, Da Costa J, Blumenfeld N. A TwoYear Follow-Up Study and Prospective Evaluation of the DSM-IV Axis V. Psychiatr Serv. 2003; 54(7):1028-30.

16. Nasrallah H, Duchesne I, Mehnert A, Janagap C, Eerdekens M. Health-related quality of life in patients with schizophrenia during treatment with long-acting, injectable risperidone. J Clin Psychiatry. 2004; 65(4):531-6.

17. Lafuente S, Francisco J, Criado I, Covarrubias C. Desinstitucionalización y calidad de vida en pacientes esquizofrénicos. El caso de Segovia. Rev Asoc Esp Neuropsiq. 2007; 27(100):319-33.

18. Ruiz M, Núñez J, Jódar R, Meana R. Calidad de vida y esquizofrenia. Estudio realizado con la población perteneciente a las Asociaciones de Salud Mental de la Comunidad Autónoma de Madrid. Madrid: Obra Social Caja Madrid; 2008.

19. Goodman M, Smith T. Measuring Quality of Life in Schizophrenia. Psychiatr Mental Health J. [Internet]. 1997. [acesso 20 março 2010]. Disponível em: http://www.medscape. com/viewarticle/430847_3

20. Awad G. Calidad de vida en esquizofrenia. Conceptos y medidas para la práctica clínica. Rev Psiquiatría Uruguay 2008; 72(2):121-9.
21. Bachrach L. Defining Chronic Mental Illness: A Concept Paper. Hosp Communi Psychiatry. 1988; 39:383-8.

22. OMS. Clasificación estadística internacional de enfermedades y problemas relacionados con la salud. - 10a. revisión Washington, D.C; 1994.

23. APA. DSM IV. Manual diagnóstico y estadístico de los trastornos mentales. Barcelona: American Psychiatric Association; 2003.

24. INEGI. XII Censo General de Población y Vivienda 2000. México: Instituto Nacional de Estadistica,Geografia e Informática; 2000.

25. CAMARA DE DipUtAdos H. Ley General de salud. México: Diario Oficial de la Federación; 1984.

26. Thompson J, Bryant B, Campbell E, Craig E, Hughes C, Rotholz D, Silverman W, Tasse M, Wehmeyer M. Supports Intensity Scale. Washington, DC: American Association on Intellectual and Developmental Disabilities; 2004.

27. Brêda M, Rosa W, Pereira MAO, Scatena MCM. Duas estratégias e desafios comuns: a reabilitação psicossocial e a saúde da família. Rev. Latino-Am. Enfermagem. 2005;13(3):450-2.

28. Lussi I, Pereira MAO, Pereira J. A proposta de reabilitação psicossocial de Saraceno: um modelo de auto-organização? Rev. Latino-Am. Enfermagem. 2006;14(3):448-56.

29. Zerbetto SR, Pereira MAO. O trabalho do profissional de nível médio de enfermagem nos novos dispositivos de atenção em saúde mental. Rev. Latino-Am. Enfermagem. 2005; 13(1):112-7.

30. Osinaga VLM, Furegato ARF, Santos JLF. Concepts of mental health and care according to mentally-ill patients and their relatives. Rev. Latino-Am. Enfermagem. 2005; 13(3):332-8.

31. Kirschbaum DIK. Concepções produzidas pelos agentes de enfermagem sobre o trabalho em saúde mental com sujeitos psicóticos em um centro de atenção psicossocial. Rev. LatinoAm. Enfermagem. 2009; 17(3):368-73.

32. Osinaga VLM, Furegato ARF, Santos JLF. Usuários de três serviços psiquiátricos: perfil e opinião. Rev. Latino-Am. Enfermagem. 2007; 15(1).

33. Koga M, Furegato ARF, Santos JLF. Opiniões da equipe e usuários sobre a atenção à saúde mental num programa de saúde da família. Rev. Latino-Am. Enfermagem. 2006;14(2):163-9.

Received: Jul. 23 2009

Accepted: May. 24 2010 